\title{
NMDA Channel Behavior Depends on Agonist Affinity
}

\author{
Robin A. J. Lester and Craig E. Jahr \\ Vollum Institute, Oregon Health Sciences University, Portland, Oregon 97201-3098
}

\begin{abstract}
We have compared the kinetic properties of NMDA receptor channels activated by exogenous agonists with those activated synaptically. Short $(4 \mathrm{msec})$ applications of L-glutamate to outside-out patches from hippocampal neurons evoked currents that decayed with a double exponential time course that was controlled by both the unbinding rate of agonist and receptor desensitization. Lower-affinity agonists evoked NMDA receptor-activated currents that had faster rates of decay and recovered from desensitization more quickly, consistent with the idea that agonists which dissociate faster allow the receptor to reach a desensitized state less often. Both synaptic and patch responses could be well fitted with a simple kinetic model comprised of two independent but identical binding sites, one open state, one closed state, and one desensitized state, all doubly liganded. Provided that the agonist has a slow unbinding rate relative to the rates into the open and desensitized states (e.g., L-glutamate), this model predicts a response with two decay phases and can thus account for the synaptic response. Since the unbinding rate is the critical determinant of the time course, different affinity transmitters would affect such properties as excitatory postsynaptic current (EPSC) duration. Of the known endogenous excitatory amino acids, only L-glutamate has an affinity for the NMDA receptor consistent with the time course of the EPSC recorded between hippocampal neurons in culture.
\end{abstract}

At many of the excitatory synapses in the vertebrate CNS, neurotransmitter, probably L-glutamate, is released from presynaptic sites and activates two types of postsynaptic receptor channels, NMDA receptors and AMPA (or non-NMDA) receptors (Mayer and Westbrook, 1987; Collingridge and Lester, 1989). The component of the excitatory postsynaptic current (EPSC) mediated by NMDA receptors has a slow onset and a very long decay phase relative to the AMPA component (Hestrin et al., 1990; Lester et al., 1990; Randall et al., 1990; Keller et al., 1991) even though both receptor types can be colocalized (Fagg and Matus, 1984) and activated by the same presynaptic event, quantally released transmitter (Bekkers and Stevens, 1989). The decay times of the two synaptic components differ more than

Received June 27, 1991; revised Sept. 23, 1991; accepted Sept. 27, 1991.

We thank Mr. J. Volk for making and maintaining the cell cultures, Drs. S. Nawy and J. T. Williams for valuable discussions and critical reading of the manuscript, and Dr. J. D. Clements for use of analysis software. This work was supported by NIH Grants RR01693 (National Biomedical Simulation Resources, Duke University) and NS21419 and The McKnight Endowment Fund for Neuroscience (C.E.J.).

Correspondence should be addressed to Craig E. Jahr, Vollum Institute L474, Oregon Health Sciences University, Portland, OR 97201-3098.

Copyright (c) 1992 Society for Neuroscience $0270-6474 / 92 / 120635-09 \$ 05.00 / 0$ 100-fold and can be accounted for, to a first approximation, by the different affinities of the receptors for L-glutamate. The AMPA receptor has a relatively low affinity (Tang et al., 1989; Trussell and Fischbach, 1989; Patneau and Mayer, 1990), and thus will become unbound very quickly, while the NMDA receptor has a much higher affinity, resulting in prolonged binding during which the channel can open repeatedly; rebinding of transmitter is not necessary for repetitive opening (Lester et al., 1990). Thus, both AMPA and NMDA components of the EPSC could be produced by a nearly instantaneous rise and $a$ fast decay of free transmitter in the synaptic cleft, not unlike that of ACh at the neuromuscular junction (Magleby and Stevens, 1972; Katz and Miledi, 1973). At a more detailed level, however, the activation of both channel types is complicated by desensitization (Tang et al., 1989; Trussell and Fischbach, 1989; Patneau and Mayer, 1990; Sather et al., 1990). Rapid desensitization of synaptic receptors could not only affect the time course of the synaptic responses but could also result in a refractory period during which a subpopulation of previously activated receptors would not be able to respond to transmitter released by subsequent stimuli.

We have combined the use of rapid application techniques (Franke et al., 1987; Tang et al., 1989; Trussell and Fischbach, 1989) and patch-clamp recording (Hamill et al., 1981) to study the kinetics of NMDA receptor channels in outside-out patches on a time scale similar to that of synaptic activation. With these techniques we can control parameters such as receptor saturation and ligand affinity that cannot be systematically altered at the synapse and can thus determine how receptor desensitization and transmitter affinity could affect synaptic transmission.

\section{Materials and Methods}

Tissue culture. Experiments were performed on hippocampal neurons from 1-3-d-old neonatal rats maintained in primary cell culture for 13 weeks, as described previously (Lester et al., 1989).

Synaptic experiments. Whole-cell patch-clamp (Warner Instruments) recordings from two cells were obtained using 3-5 M pipettes filled with an internal solution containing K-gluconate, $150 \mathrm{mM}$; $\mathrm{NaCl}, 10$ mM; HEPES, $10 \mathrm{~mm}$; and EGTA, $10 \mathrm{~mm}$; adjusted to pH 7.4 with $\mathrm{KOH}$. The control external solution contained $\mathrm{NaCl}, 160 \mathrm{~mm} ; \mathrm{KCl}, 3 \mathrm{~mm}$; $\mathrm{CaCl}_{2}, 2 \mathrm{~mm}$; HEPES, $10 \mathrm{~mm}$; glycine, $0.02 \mathrm{~mm}$; picrotoxin, $0.05 \mathrm{~mm}$; and 6-cyano-7-nitroquinoxaline-2,3-dione (CNQX), $0.005 \mathrm{~mm}$; adjusted to $\mathrm{pH} 7.4$ with $\mathrm{NaOH}$. Both pre- and postsynaptic neurons were voltage clamped. A brief (1-2 msec) voltage step from a holding potential of $-60 \mathrm{mV}$ evoked an action potential in the presynaptic cell, and the postsynaptic current was clamped at potentials in the range of -60 to $-90 \mathrm{mV}$. Synaptic currents were evoked at $10 \mathrm{sec}$ intervals, low-pass filtered at $1 \mathrm{kHz}$, and digitally sampled at $2 \mathrm{kHz}$.

Outside-out patch recordings. Outside-out patch recordings (Axopatch-1C, Axon Instruments) from hippocampal neurons were obtained using pipettes containing Cs-gluconate or Cs-methanesulfonate, $140 \mathrm{~mm}$; $\mathrm{NaCl}, 10 \mathrm{~mm}$; HEPES, $10 \mathrm{~mm}$; and EGTA, $10 \mathrm{~mm}$; adjusted to $\mathrm{pH} 7.4$ with $\mathrm{CsOH}$. Control external solutions contained $\mathrm{NaCl}, 160 \mathrm{~mm} ; \mathrm{KCl}$, $3 \mathrm{~mm}$; HEPES, $5 \mathrm{~mm}$; glycine, $0.01 \mathrm{~mm}$; and CNQX, $0.002 \mathrm{~mm}$; adjusted 
to $\mathrm{pH} 7.4$ with $\mathrm{NaOH}$. Fxternal $\mathrm{Ca}^{2+}$ ranged from 0 (1 mM EGTA) to $2 \mathrm{mM}$. In the majority of experiments, $\mathrm{Ca}^{2+}$-free medium was used to help prevent slow rundown of NMDA currents. External solutions were gravity fed into each of the two lumens of glass $\theta$-tubing (Sutter Instruments, San Rafael, CA) pulled to an overall tip diameter of about 200 $\mu \mathrm{m}$. The patch was positioned within $50 \mu \mathrm{m}$ of the tip, near the interface formed between the continuously flowing control and drug solutions. The solution exchange was made by rapidly moving the solution interface across the tip of the patch pipette using a piezoelectric translator (Physik Instrumente, model P245.30) attached to the $\theta$-tube. Agonist applications were made at $10-20 \mathrm{sec}$ intervals. In some experiments, four-barreled glass tubing (Vitro Dynamics, Inc., Rockaway, NJ) was used instead of $\theta$-tubing so that two agonists could be compared on the same patch. In these experiments, the concentration of $\mathrm{Na}^{+}$and the $\mathrm{pH}$ (Tang et al., 1990; Traynelis and Cull-Candy, 1990) of the two agonist solutions were carefully matched. Outside-out patches were clamped at $-60 \mathrm{mV}$, and the currents were low-pass filtered at $0.1-1.0 \mathrm{kHz}$ and digitally sampled at 500-2000 Hz. High-purity salts were obtained from Aldrich (Gold label). Other chemicals were obtained from Sigma except for CNQX (Cambridge Research Biochemicals and Tocris) and glycine (BioRad).

The speed and completeness of solution changes were routinely tested at the end of a recording by "blowing out" the membrane and monitoring the open tip current due to differences in liquid junction potentials in the control and drug solutions (usually the drug solution was diluted with water 50:1). These "open tip" currents (see Fig. 1 $A$, upper trace) are shown above the patch responses in all figures. The speed of solution change at the membrane was tested by switching between an external solution containing $160 \mathrm{~mm} \mathrm{NaCl}$ to one with $80 \mathrm{~mm} \mathrm{NaCl}$ (glucose added to maintain constant osmolality) in the continuous presence of L-glutamate $(1 \mu \mathrm{M})$ and glycine $(10 \mu \mathrm{M})$. Averages of records in which the switch occurred when no channels wcre open wcre subtracted from averages of records during which the switch occurred when a single channel was open. The lower record in Figure $1 A$ illustrates this and reflects the change in $\mathrm{Na}^{+}$concentration at the membrane surface.

All experiments were performed at room temperature $\left(25^{\circ} \mathrm{C}\right)$.

Data analysis. The decay phases of responses were fitted with exponentials either by eye or by a least-squares fitting routine. Fits obtained by both methods differed insignificantly. All data are expressed as the mean \pm SEM. Statistical analysis was performed using unpaired $t$ tests. Averaged outside-out patch responses and EPSCs were fitted with the model described in the Results using a least-squares fitting procedure in the SCoPfit program from the National Biomedical Simulation Resource at Duke University.

\section{Results}

Comparison of synaptic and outside-out patch NMDA currents In the presence of $2 \mu \mathrm{M} C \mathrm{CNX}$ and the absence of external $\mathrm{Mg}^{2+}$, a 4 msec application of $\mathrm{L}$-glutamate $(200 \mu \mathrm{M})$ to an outside-out patch produced prolonged periods of multiple NMDA channel openings (Fig. $1 B$ ), as previously described (Lester et al., 1990). The time course of the average of many single responses was remarkably similar to the NMDA EPSC (Fig. 1C). The decay of both the patch and the NMDA EPSC could be fitted by the sum of two exponentials. At $-60 \mathrm{mV}$, the time constant of the first exponential was $70.5 \pm 6.2 \mathrm{msec}(n=11)$ for the synapse and $67.9 \pm 2.1 \mathrm{msec}(n=23)$ for the patch. The second time constant was more variable but was in the range of 326-884 msec for both the patch and the synapse. The relative amplitudes of the first components were $80.0 \pm 1.1 \%$ and 63.1 $\pm 4.0 \%$ for the patch and synaptic currents, respectively.

\section{The decay of the NMDA receptor current is due to receptor desensitization and dissociation of agonist}

It has been argued that the rate-limiting step for termination of the synaptic NMDA current is channel closure rather than clearance of free transmitter from the synaptic cleft (Hestrin et al., 1990; Lester et al., 1990). L-Glutamate remains bound to NMDA receptors for a prolonged period following brief applications
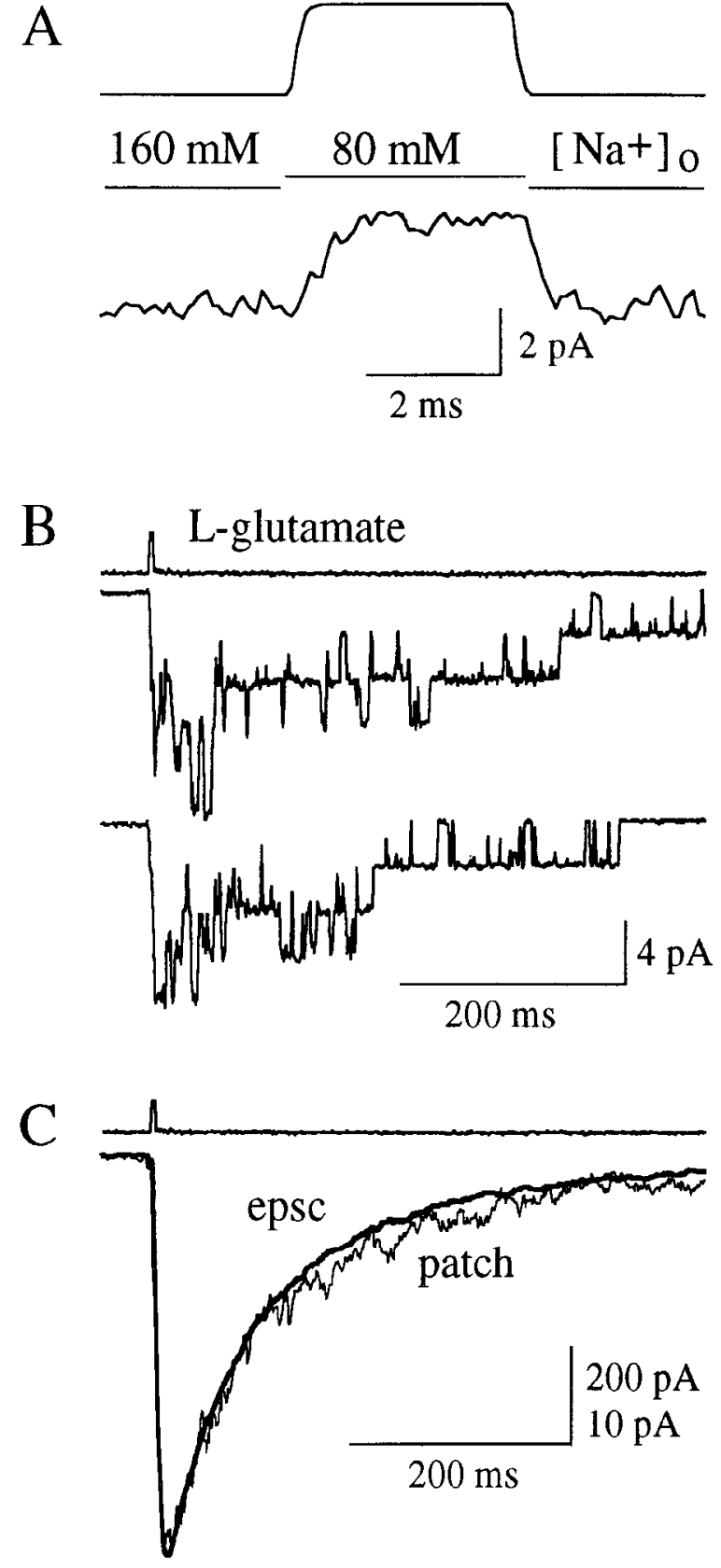

Figure 1. Comparison of the NMDA EPSC with current activated by short applications of L-glutamate to outside-out patches. $A$, Open tip current recorded during a $4 \mathrm{msec}$ step into a solution containing $50 \%$ of the control $\mathrm{NaCl}$ concentration (upper trace) and averaged open NMDA channel current (lower trace) recorded from an outside-out patch during the same $4 \mathrm{msec}$ solution change as above (see Materials and Methods). Amplitude calibration applies only to the outside-out patch current. $B$, Single-channel currents induced in an outside-out patch by a 4 msec pulse of $200 \mu \mathrm{M} \mathrm{L}$-glutamate. Time of agonist application is indicated in this and subsequent figures by the open tip response (upper trace) obtained following the experiment (see Materials and Methods). $C$, Superimposition of an average of 24 responses of an outside-out patch to $4 \mathrm{msec}$ applications of $200 \mu \mathrm{M}$ L-glutamate and an NMDA EPSC recorded between a pair of neurons.

(Lester et al., 1990), and since in the continued presence of agonist the NMDA receptor desensitizes rapidly (Sather et al., 1990), it is conceivable that desensitization as well as the unbinding of agonist contributes to the decay time course of the 
A

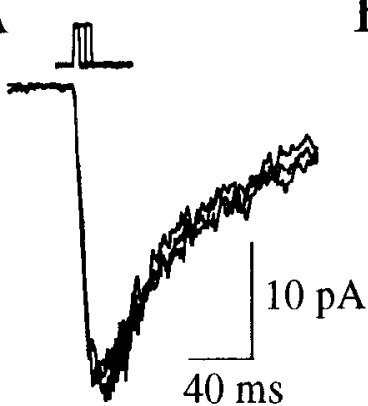

B

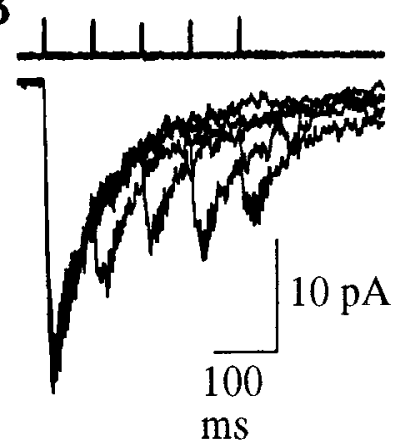

Figure 2. Desensitization of NMDA receptors contributes to the decay of currents evoked by brief pulses of L-glutamate. $A$, Averaged currents in an outside-out patch induced by 4,8 , and $12 \mathrm{msec}$ pulses of $200 \mu \mathrm{M}$ L-glutamate. $B$, Superimposed currents from the same patch as $A$ in response to paired pulses $(4 \mathrm{msec})$ of $200 \mu \mathrm{M} \mathrm{L}$-glutamate separated by intervals of $80,160,240$, and $320 \mathrm{msec}$.

EPSC. Paired-pulse paradigms can be used to determine the degree of receptor desensitization, but quantitative results depend critically on the same population of receptors being exposed to agonist by both applications and on a sufficient concentration of agonist reaching the receptors so that they are saturated. At the synapse the probability of release at each release site is certainly less than one, and it is still unknown if receptor saturation occurs at those sites where release occurs.

If outside-out patches are used to test for receptor desensitization, the question of multiple release sites is no longer an issue and saturation of NMDA receptors can be readily tested. By increasing the duration of the application of agonist and measuring the amplitude of the patch current, the maximum
Table 1. Summary of decay time constants for different affinity NMDA ligands

\begin{tabular}{llllr} 
& \multicolumn{1}{l}{$\tau_{1}$} & $\tau_{2}$ & $\% \tau_{1}$ & $n$ \\
\hline NMDA EPSC & $70.5 \pm 6.2$ & $417 \pm 76$ & $63.1 \pm 4.0$ & 11 \\
L-Glutamate & $67.9 \pm 2.1$ & $553 \pm 33$ & $80.0 \pm 1.1$ & 23 \\
L-Homocysteate & $51.5 \pm 3.0$ & $316 \pm 36$ & $88.7 \pm 1.9$ & 6 \\
L-Aspartate & $42.1 \pm 2.3$ & $210 \pm 20$ & $87.5 \pm 2.3$ & 13 \\
NMDA & $41.3 \pm 3.9$ & $187 \pm 13$ & $94.8 \pm 2.8$ & 4 \\
L-Cysteate & $31.0 \pm 2.1$ & $164 \pm 20$ & $95.1 \pm 2$ & 10
\end{tabular}

Data show the first $\left(\tau_{1}\right)$ and second $\left(\tau_{2}\right)$ time constants from a double exponentia fit of the current decay produced by synaptic stimulation and application of brief pulses of agonists to outside-out patches. The relative amplitude of the first exponential $\left(\% \tau_{1}\right)$ is also shown. Data are expressed as mean \pm SEM in msec

current amplitude should reflect saturation of NMDA receptors. This experiment is shown in Figure $2 A$ and demonstrates that saturation occurrcd with $4 \mathrm{mscc}$ applications of $200 \mu \mathrm{M} \mathrm{L}$-glutamate. Shorter applications resulted in smaller responses, indicating that the concentration of L-glutamate at the receptors did not reach a saturating concentration. If the L-glutamate concentration was increased to $3 \mathrm{~mm}$, pulses as short as $0.8 \mathrm{msec}$ produced maximal responses. After determining pulse durations that produced saturating responses, a second pulse of L-glutamate of the same duration was applied at increasing intervals after the first pulse (Fig. 2B). If unbinding of agonist alone determines the decay of the response, then the second pulse should produce a response with the same peak amplitude as the first. However, with L-glutamate this was not the case. Considerable desensitization of NMDA receptors occurs even following a brief agonist application.
A
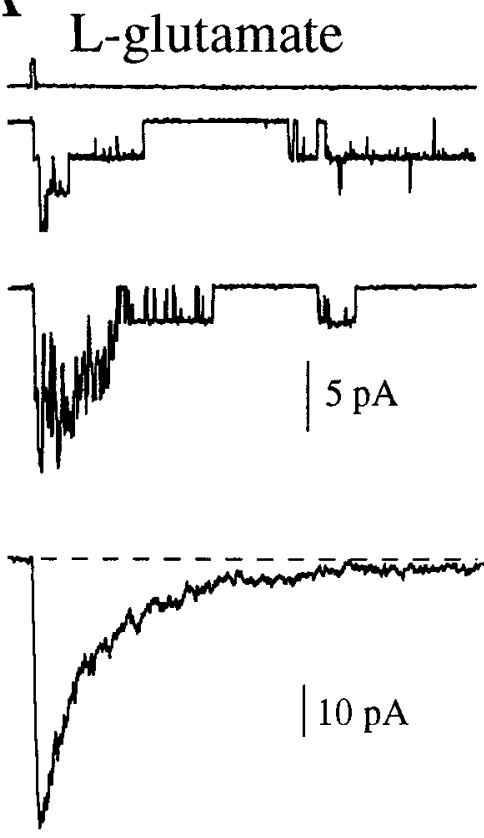

B
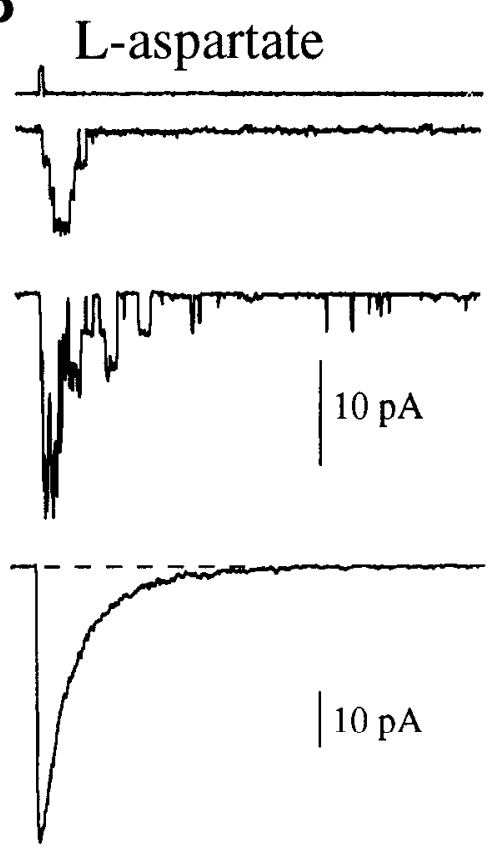
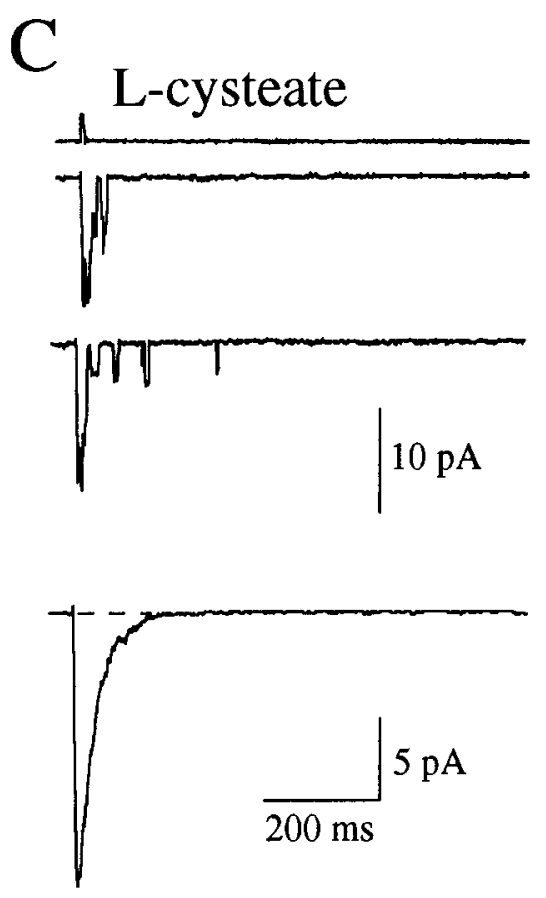

Figure 3. The time course of the NMDA channel current elicited by short applications of agonist is determined by the affinity of the agonist. Single-channel (upper traces) and averaged (lower traces) currents induced in outside-out patches by 4 msec applications of $200 \mu \mathrm{M} L$-glutamate $(A), 2 \mathrm{~mm}$ L-aspartate $(B)$, and $20 \mathrm{~mm}$ L-cysteate $(C)$. 
A
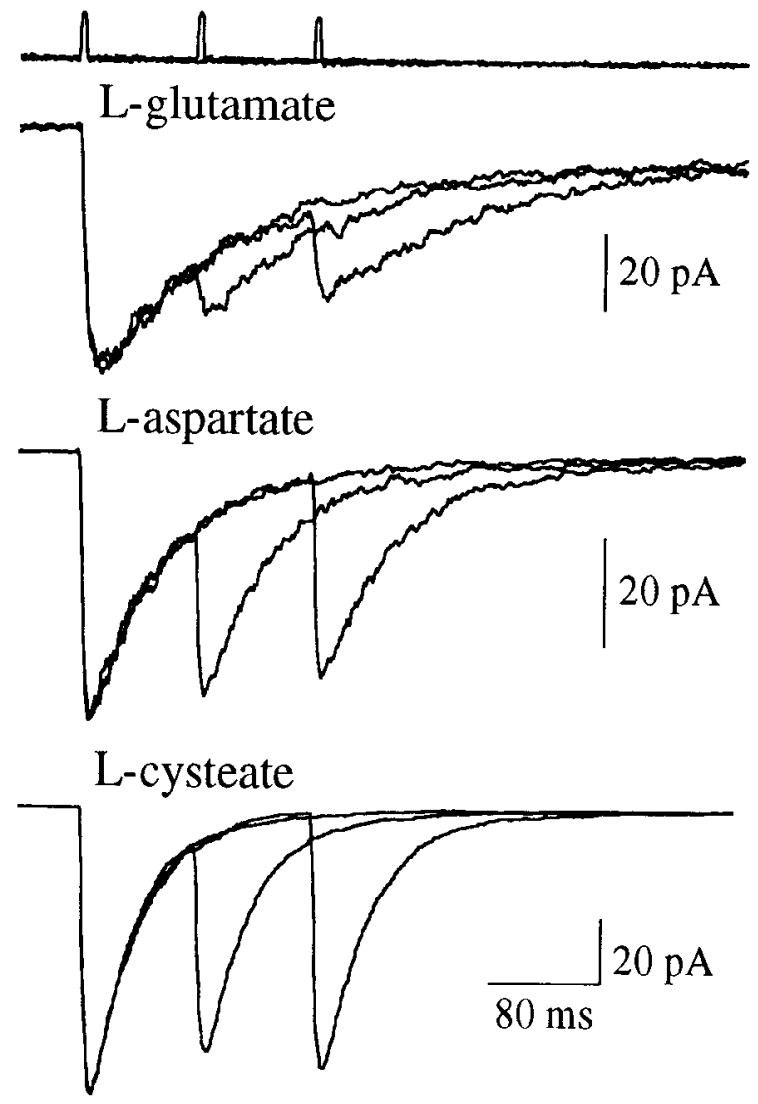

B
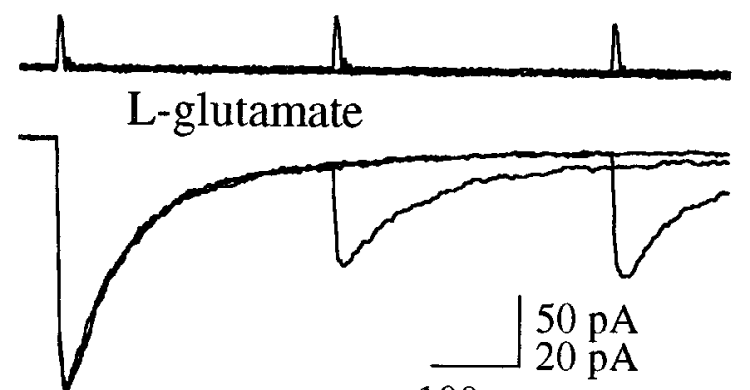

L-cysteate $\quad 100 \mathrm{~ms}$

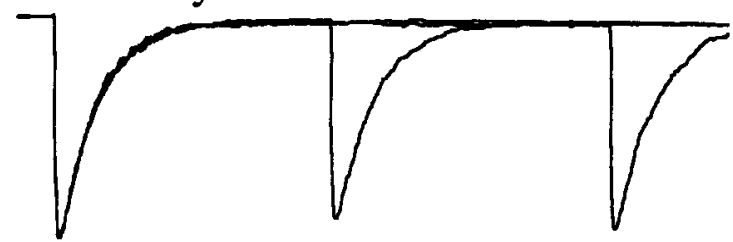

C

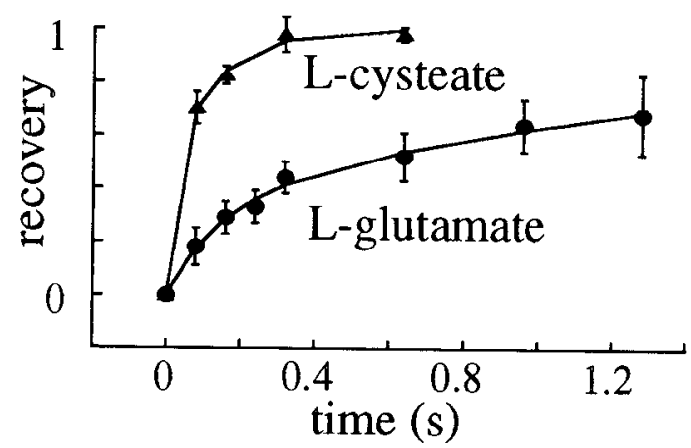

Figure 4. Brief applications of lower-affinity agonists induce less desensitization than L-glutamate. $A$, Superimposed average currents recorded in outside-out patches in response to paired-pulse applications of $200 \mu \mathrm{M} \mathrm{L}$-glutamate, $2 \mathrm{mM} \mathrm{L}$-aspartate, and $20 \mathrm{~mm} \mathrm{~L}$-cysteate, at interpulse intervals of 80 and $160 \mathrm{msec}$. $B$, Superimposed average currents in two outside-out patches evoked by paired pulses of $200 \mu \mathrm{M}$ L-glutamate and $20 \mathrm{mM}$ L-cysteate applied at intervals of 320 and $640 \mathrm{msec}$. $C$. The time courses of recovery of the current induced by 4 msec saturating pulses of L-glutamate $(200 \mu \mathrm{M}$; circles) and L-cysteate $(20 \mathrm{~mm}$; triangles). The amplitude of the second response in the paired-pulse application was measured from the point of inflection off the first, expressed as a fraction of the control current and plotted against the paired-pulse interval. The recovery process from L-glutamate does not reflect a simple process since fitting the time course of recovery required a double exponential with time constants of 120 and $1450 \mathrm{msec}$. Error bars indicate SD.

\section{Behavior of other NMDA agonists}

Along with L-glutamate, several other naturally occurring NMDA agonists have been suggested as fast excitatory neurotransmitters (for review, see Collingridge and Lester, 1989). If the time course of the NMDA EPSC is dependent ultimately on how long the transmitter remains bound to the NMDA receptor, then its decay should be determined by the affinity of the transmitter released, as it would be expected that the affinity of the agonist would reflect, in part, its dissociation rate from the receptor. Since the action of other NMDA agonists could not be directly tested at the synapse, their behavior was compared to that of L-glutamate on the outside-out patch. L-Aspartate, itself a transmitter candidate, and the sulfur-containing amino acid L-cysteate were chosen since their respective affinities for the NMDA receptor are about 10 - and 100 -fold lower than that of L-glutamate (Olverman et al., 1988; Patneau and Mayer, 1990).

As predicted, the rate of decay of currents produced by brief applications of these agonists increased as the agonist affinity decreased, suggesting that the dissociation rate of the agonist limited the time course of the response (Fig. 3, Table 1). Al- though the first component of decay was faster for L-aspartate and L-cysteate than for L-glutamate, the change in the slower component was more pronounced for the lower-affinity agonists. In fact, for L-cysteate the second component accounted for less than $5 \%$ of the total current (see Table 1). The diminution of the slow component with decreasing affinity reflects, at least in part, a decreased occurrence of prolonged bursts of channel openings in the raw records (Fig. 3). Other NMDA agonists tested resulted in decay time courses in accordance with their affinities. Thus, the decay of the current produced by L-homocysteate, which has an affinity four to five times lower than L-glutamate (Olverman et al., 1988; Patneau and Mayer, 1990), was intermediate between that of L-glutamate and L-aspartate (Table 1).

Unlike the responses to L-glutamate, $4 \mathrm{msec}$ applications of I-cysteate (20-30 mM) did not activate currents of maximal amplitude even though, at these concentrations, receptor saturation must have occurred. The L-cysteate response amplitude increased with increases in application duration until the duration equaled the time to peak of the L-glutamate response $(\sim 15 \mathrm{msec})$. This suggests that the unbinding rate of $\mathrm{L}$-cysteate is fast enough for a significant proportion of receptors to become 
A

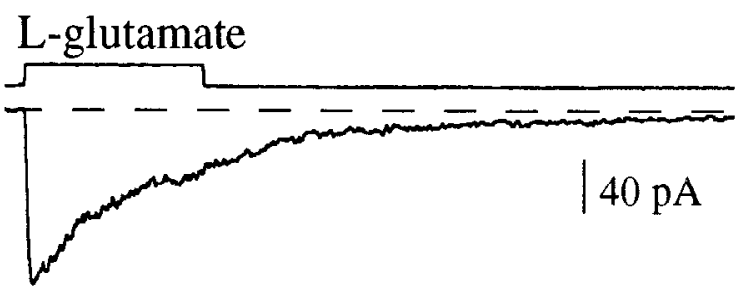

B

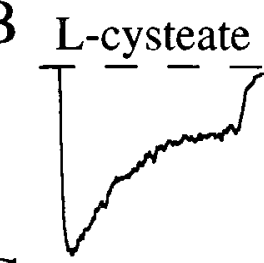

C

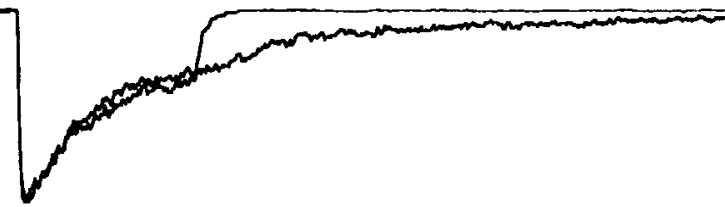

$\mathrm{D}$

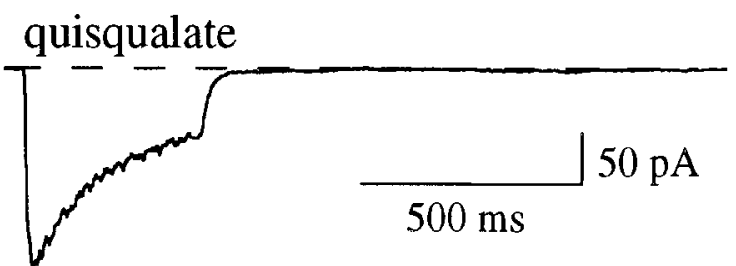

Figure 5. The rate into desensitization due to prolonged activation of NMDA receptors is similar for different-affinity agonists. Ensemble averages of currents induced in outside-out patches by $400 \mathrm{msec}$ pulses of $200 \mu \mathrm{M} \mathrm{L}$-glutamate $(A)$ and $20 \mathrm{mM} \mathrm{L}$-cysteate $(B) . C$, The traces in $A$ and $B$ have been normalized and superimposed and show that the rate into and extent of desensitization during the application of both agonists are similar, but the decay of the current following removal of agonists is much faster for L-cysteate. $D$, Ensemble average of currents activated by $400 \mathrm{msec}$ applications of $20 \mathrm{~mm}$ quisqualate.

unbound immediately after a short application whereas there is very little unbinding of L-glutamate during this period (see Fig. $6 B)$.

The amount of desensitization resulting from brief activation of NMDA receptors decreased with decreasing agonist affinity as demonstrated with paired-pulse applications (Fig. $4 A$ ). $\mathrm{Re}-$ sponses to $\mathrm{L}$-cystcate completely recovered at an interpulse interval of $320 \mathrm{msec}$, whereas after this period only $40 \%$ of the receptors recovered from exposure to L-glutamate (Fig. $4 B$ ). In order to examine the rate at which NMDA receptors become available for reactivation following brief activation by L-glutamate and L-cysteate, the amplitude of the second response (measured from the point of inflection off the decay of the first response) was expressed as a fraction of the first response and plotted against the time of the second application (Fig. 4C). These data support the suggestion that lower-affinity agonists unbind faster and that fewer desensitized receptors result from brief applications of lower-affinity ligands. Responses to longer applications of different-affinity agonists showed that the rate of desensitization was not agonist dependent as long as the concentration of agonist was high enough for the receptors to be saturated (Fig. 5). However, as with short pulses, the tail
A
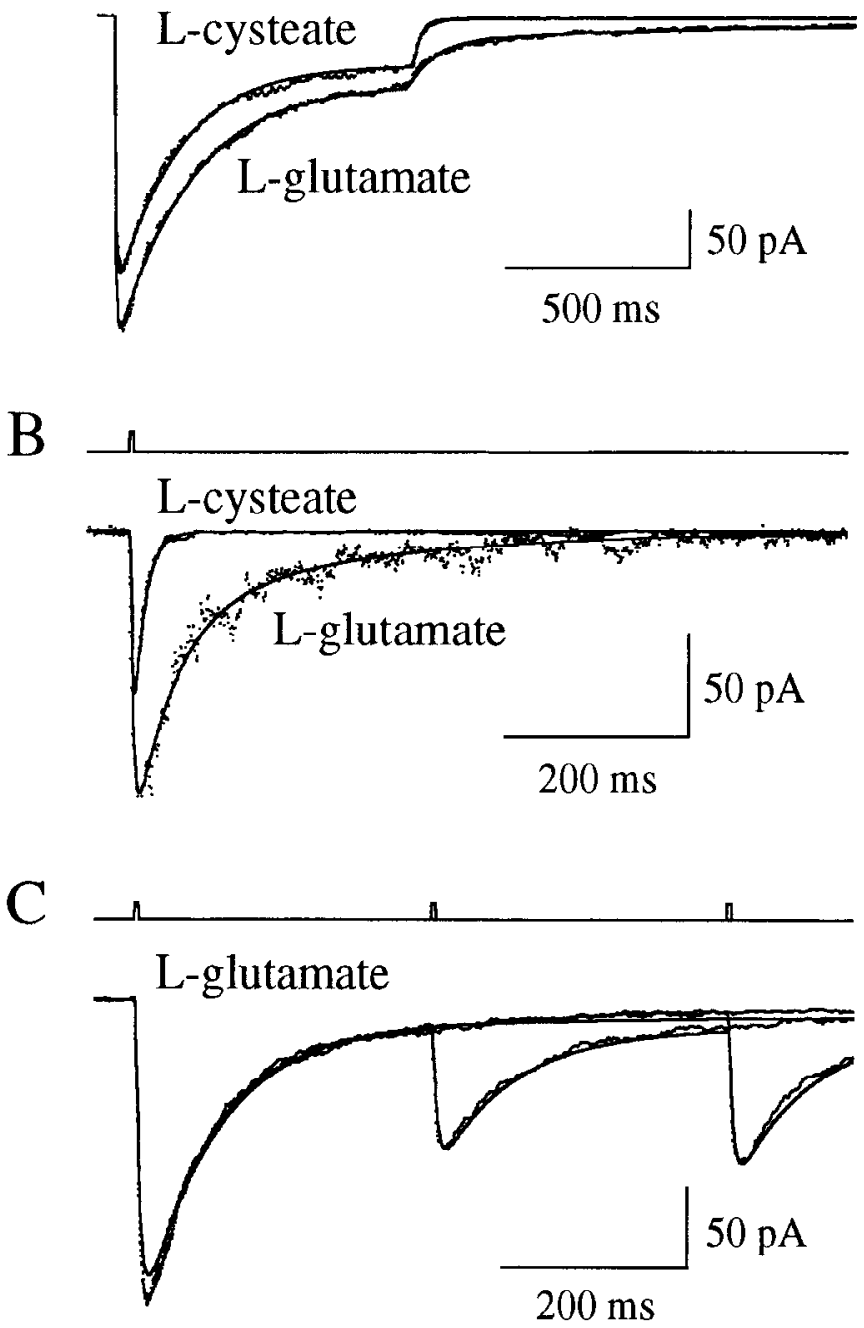

Figure 6. L-Cysteate and L-glutamate responses can be simulated by a simple kinetic model. $A$, Superimposed averages of responses (dots) of the same patch to $400 \mathrm{msec}$ applications of L-glutamate $(200 \mu \mathrm{M})$ and L-cysteate $(30 \mathrm{~mm})$. Applications of the two agonists were interleaved at periods of $20 \mathrm{sec}$. The simulated response ( $\ln$ in line) to the L-cysteate current was produced by the same rate constants that were used to fit the L-glutamate response except that the unbinding rate was increased and the opening rate was decreased. $B$, Superimposed averages of responses of a different patch to $4 \mathrm{msec}$ applications of $\mathrm{L}$-glutamate (200 $\mu \mathrm{M})$ and $\mathrm{L}$-cysteate $(20 \mathrm{mM})$. Interleaved applications were made every $20 \mathrm{sec}$. The simulated responses were obtained in the same manner as in $A$. $C$, Averaged responses of a patch to paired applications of L-glutamate $(200 \mu \mathrm{M})$. The single application and paired pulses (320 and $640 \mathrm{msec}$ ) were interleaved. The simulated responses were fitted to the paired-pulse data at the $640 \mathrm{msec}$ interval. The resulting rate constants were used to predict the $320 \mathrm{msec}$ data.

current at the end of the application decayed faster with the lower-affinity agonists (Fig. 5).

A practical result of these observations is the ability to distinguish definitively between responses produced by low- and high-affinity agonists. Thus, although quisqualate has been suggested to be a weak NMDA agonist with an affinity similar to L-cysteate (Grudt and Jahr, 1990), there is evidence that at least some of its action at the NMDA receptor may be due to contamination by L-glutamate (Cha et al., 1989). If contaminating 
Table 2. NMDA receptor model rate constants

\begin{tabular}{|c|c|c|c|c|}
\hline & \multicolumn{2}{|l|}{ Long pulse } & \multirow[b]{2}{*}{ Paired pulse } & \multirow[b]{2}{*}{ NMDA EPSC } \\
\hline & L-Glutamate & L-Cysteate & & \\
\hline$k_{\mathrm{off}}$ & $4.7 \pm 0.5$ & $62.6 \pm 15^{a}$ & $3.6 \pm 0.6$ & $6.7 \pm 1.3$ \\
\hline$k_{d}$ & $8.4 \pm 1.2$ & $8.9 \pm 0.7$ & $14.7 \pm 2.3^{b}$ & $15.2 \pm 3.1$ \\
\hline$k_{r}$ & $1.8 \pm 0.4$ & $2.2 \pm 0.7$ & $1.9 \pm 0.5$ & $9.4 \pm 1.5^{c}$ \\
\hline$\beta$ & $46.5 \pm 2.8$ & $39.1 \pm 5.9$ & $79.7 \pm 9.2^{d}$ & $83.8 \pm 13.1^{d}$ \\
\hline$\alpha$ & $91.6 \pm 7.1$ & $95.8 \pm 11.9$ & $121 \pm 20.9$ & $83.8 \pm 13.1$ \\
\hline$n$ & 11 & 4 & 7 & 5 \\
\hline
\end{tabular}

The table shows the mean $\left( \pm\right.$ SEM) rate constants $\left(\mathrm{sec}^{-1}\right)$ obtained from the fitting of patch and synaptic data with the model (see Results). The long pulses of L-glutamate $(200 \mu \mathrm{M})$ and L-cysteate $(20-30 \mathrm{mM})$ ranged from $400 \mathrm{msec}$ to $2 \mathrm{sec}$, and the paired-pulse data were obtained with L-glutamate at an interpulse interval of 640 msec. $k_{\text {off }}$ unbinding rate; $k_{d}$, desensitization rate; $k_{n}$ resensitization rate; $\beta$, opening rate; $\alpha$, closing rate.

${ }^{a}$ The unbinding rate, $k_{\mathrm{off}}$ for L-cysteate was significantly faster than L-glutamate $(p<0.0001)$.

${ }^{b}$ The rate of desensitization, $k_{d}$, was significantly faster for paired pulses compared to long pulses of L-glutamate $(p<0.035)$.

c The rate of resensitization, $k_{r}$ for the EPSC was significantly faster than the patch responses $(p<0.0001)$.

${ }^{d}$ The opening rates for paired pulses and synaptics are significantly faster than the long-pulse patch responses $(p<0.001)$.

L-glutamate contributed significantly to the current, a long tail current should be produced by high concentrations of quisqualate. This was not the case. The tail current produced by $400 \mathrm{msec}$ applications of $20 \mathrm{~mm}$ quisqualate was extremely fast, not dissimilar to that of L-cysteate (Fig. $5 D$ ). This indicates that quisqualate, while a much higher-affinity agonist at the AMPA receptor, is also an agonist at the NMDA receptor.

\section{Model of NMDA receptor activation}

In order to describe the differences in response time courses evoked by low- and high-affinity agonists, we have used a model with two independent binding sites (Patneau and Mayer, 1990; Clements and Westbrook, 1991) to fit the data using a leastsquares fitting procedure (see Materials and Methods). The simplest model that can fit all the data reasonably is

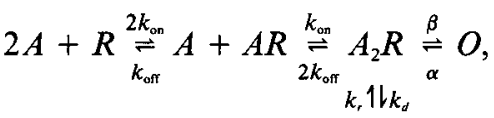

$$
\begin{aligned}
& A_{2} D
\end{aligned}
$$

where $R$ represents an NMDA receptor with two binding sites for agonist, $A$. $O$ is the open state of the channel and $A_{2} D$ is the desensitized state. $k_{\text {on }}$ and $k_{\text {off }}$ are the binding and unbinding rates, $\beta$ and $\alpha$ are the opening and closing rates, and $k_{d}$ and $k_{r}$ are the rates of desensitization and resensitization, respectively. Responses to long applications ( $400 \mathrm{msec}$ to $2 \mathrm{sec}$ ) of L-glutamate $(200 \mu \mathrm{M})$ from 11 patches were fitted assuming that $30 \%$ of the channels in the patch were open at the peak of the response (C. E. Jahr, unpublished observations). Since we used supermaximal concentrations of agonists, our data will not provide accurate information concerning the binding rate, $k_{\text {on }}$. Therefore, $k_{\mathrm{on}}$ was constrained to $5 \mu \mathrm{M}^{-1} \sec ^{-1}$ as reported by Clements and Westbrook (1991), but the rest of the rate constants were allowed to vary in these initial fits. Table 2 lists the average rate constants and their variability across patches. In the continued presence of agonist, patches displayed a large variation in the
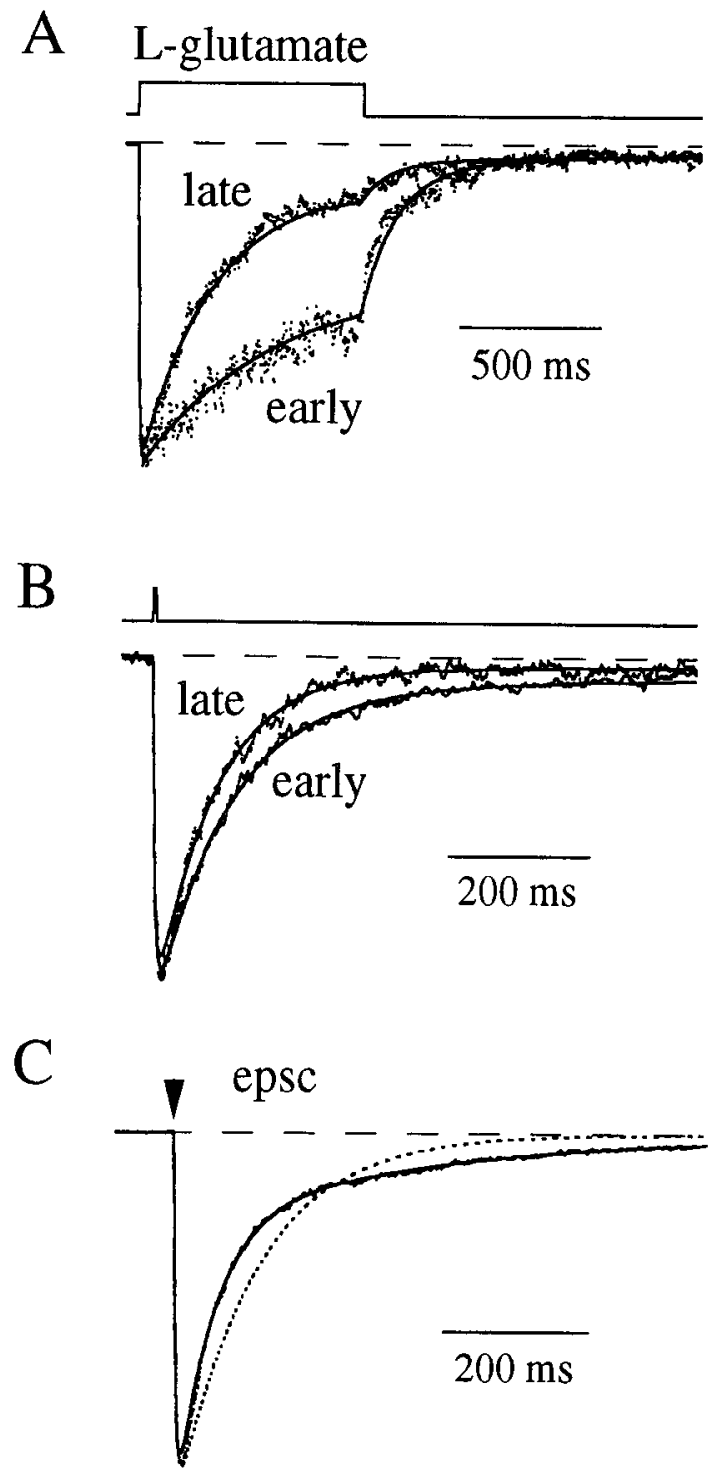

Figure 7. Prediction of time-dependent changes in patch responses to L-glutamate. $A$, Averages of currents from an outside-out patch produced by $800 \mathrm{msec}$ applications of $200 \mu \mathrm{M}$ L-glutamate showing an increase in desensitization rate with recording time (dots). The early trace is an average of the first three records after pulling the patch. The late trace is the average of eight subsequent records. $B$, Averages of currents in a patch produced by $4 \mathrm{msec}$ applications of $200 \mu \mathrm{M}$ L-glutamate showing an increase in decay rate of the current with recording time. Due to the rapid change in the rate of decay after patch excision, only the first three responses were averaged in order to obtain an accurate decay rate (early). The late response was recorded approximately $10 \mathrm{~min}$ later. The fitted late responses (thin lines) in both $A$ and $B$ were obtained by constraining all of the rate constants used in fitting the early responses, with the exception of the rates into $\left(k_{d}\right)$ and out of $\left(k_{r}\right)$ desensitization, which were allowed to vary. $C$, Superimposition of an NMDA EPSC and simulated responses with (continuous line) and without (broken line) a desensitized state. The EPSC was fitted with the model using rate constants similar to those derived from fitting patch responses to $4 \mathrm{msec}$ applications of L-glutamate $(200 \mu \mathrm{M})$.

extent of desensitization that was reflected by a range of modeled rates into (3.0-16 $\left.\mathrm{sec}^{-1}\right)$ and out of (0.65-4.47 $\left.\mathrm{sec}^{-1}\right)$ desensitization. Because of the patch to patch variation in desensitization, comparisons of the responses evoked by high- and lowaffinity agonists were most meaningful when they were obtained 
by interleaving applications of two agonists on the same patch. L-Glutamate $(200 \mu \mathrm{M})$ and L-cysteate $(30 \mathrm{~mm})$ evoked currents from the same patch that clearly differed not only in the rate of decay at the end of the application but also in peak amplitude (Fig. 6A,B). When the $\mathrm{L}$-cysteate response was scaled to match the amplitude of the L-glutamate response, only the unbinding rate constant $\left(k_{\text {off }}\right)$ had to be increased $(8.4 \pm 1.3$-fold; $n=3$ ) for the model to produce good fits of the data. In order for the model to account for the lower-amplitude $\mathrm{L}$-cysteate response, the opening rate $(\beta)$ had to be slowed by $33.0 \pm 6.7 \%(n=3$; Fig. $6 A, B)$. Saturating concentrations of $\mathrm{L}$-aspartate $(2 \mathrm{~mm})$ also evoked smaller responses $(65.3 \pm 8.5 \% ; n=7)$ than L-glutamate $(200 \mu \mathrm{M}$ or $2 \mathrm{mM}$ ) in the same patches. Although the model could be used to fit the responses to L-aspartate and L-cysteate by using slower opening rates than those needed to fit L-glutamate responses, the high concentrations of agonists used in these experiments could theoretically result in sufficient channel block to account for at least some of the decreased efficacy as it does at the ACh receptor (Marshall et al., 1991). Using the rate constants derived from the long applications of L-glutamate, the model could also fit the behavior of responses to short pairedpulse applications of L-glutamate (Fig. 6C), although a faster rate into the desensitized state was required (1.7-fold; see Table 2).

As well as the variation from patch to patch, many patches displayed a time-dependent increase in the rate of desensitization that became apparent when responses recorded very soon after patch formation ("early") were compared to those recorded after 1 or 2 min ("late"; Fig. $7 A$ ). The late responses were well fitted using the same rate constants used to fit the early responses, with the exception that the rate into the desensitized state $\left(k_{d}\right)$ had to be increased from $3.2 \pm 0.4$ to $6.1 \pm 0.7 \mathrm{sec}^{-1}(n=6)$. This was also reflected by an increase in the rate of decay of responses to short pulses of L-glutamate (Fig. $7 B$ ). Since the kinetics of the patch response changed very rapidly after patch formation, accurate data from unaltered patches were rarely obtained. Thus, all of the data in this article are from "late" patches.

Unlike the patch responses, the time course of the NMDA component of EPSCs did not change systematically with recording time. The EPSC could be fitted by the same model (assuming a $4 \mathrm{msec}$ pulse of $200 \mu \mathrm{M}$ transmitter) with rate constants that were well within the range of those generated in fitting the patch responses to L-glutamate (Fig. $7 C$; see Table 2 ) except for the rate out of the desensitized state, which required, on average, a fivefold increase to account for the larger amplitude of the late component. If the desensitized state is eliminated from the model, the waveform generated decays with a single exponential time course and does not have a slow late decay phase; thus, it clearly does not resemble the EPSC (Fig. 7C).

\section{Discussion}

\section{Channel kinetics and NMDA synaptic decay}

Previous studies have suggested that free transmitter need only be present in the synaptic cleft for at most a few milliseconds (Hestrin et al., 1990; Lester et al., 1990). If this is true, then the kinetics of the unbinding of transmitter from the receptors will become the overriding factor in determining the decay time course of the EPSC just as at the neuromuscular junction (Magleby and Stevens, 1972; Colquhoun et al., 1977). The evidence presented in this article indicates that the decay of the patch response does not simply reflect closure of the NMDA channel and subsequent unbinding of agonist since this would predict a single exponential decay, but instead a substantial number of receptors become desensitized with short applications of highaffinity agonists like L-glutamate. One explanation for the twocomponent decay is that following a burst of openings there is a high probability that the channel will burst again or enter a desensitized state rather than becoming unbound. This is consistent with the slow recovery seen with $\mathrm{L}$-glutamate in the pairedpulse experiments. From this desensitized state the channel can reenter the open state many times before the agonist finally dissociates and thus could account for the slow second component of the response. Such a scheme, as formalized by the model in the Results, can also account for the two-component NMDA EPSC.

We derive support for the kinetic scheme from the actions of lower-affinity NMDA receptor ligands. Brief applications of agonists with lower affinities evoked responses that had more rapid initial decays and could be fitted with the model if a faster unbinding rate $\left(k_{\text {off }}\right)$ was assumed. According to the kinetic scheme, faster agonist dissociation would result in fewer receptors remaining in the desensitized state and therefore fewer late openings and a smaller slow component. For agonists like L-cysteate, the slow component is almost absent because unbinding rather than reopening is much more likely to occur when exiting from either the open or the desensitized state. Unlike nicotinic ACh receptors at the neuromuscular junction where the time course of recovery from desensitization is not agonist dependent (Katz and Thesleff, 1957; Feltz and Trautmann, 1982; Boyd, 1987), NMDA receptor recovery was much faster with loweraffinity agonists. For the $\mathrm{ACh}$ receptor, agonist-independent recovcry indicates that the rates between desensitized and activatible states (including the unliganded species of these states) are slower than the rates of agonist binding and unbinding and thus rate limiting (Katz and Thesleff, 1957; Feltz and Trautmann, 1982; Boyd, 1987). As recovery of NMDA receptors was clearly dependent on the affinity of the agonist (see Fig. 4), we suggest that the unbinding rate of agonist is rate limiting in the recovery process and that if an unbound desensitized state exists, it either is in relatively rapid equilibrium with the unbound activatible state or is reached infrequently. Furthermore, the prolonged second component of the current parallels the time course of recovery from L-glutamate, indicating that channel opening and thus liganded receptors can exist for prolonged periods. These data are consistent with the major component of NMDA receptor desensitization being due to a long-lived or repeatedly accessed liganded state.

\section{Comparison to steady-state single-channel recordings}

Gibb and Colquhoun (1991) have reported that in recordings of NMDA channel activity from outside-out patches in the continuous presence of very low concentrations of L-glutamate, clusters of openings occur that are on average $21.6 \mathrm{msec}$ long (range, 11-43 msec from patch to patch). This is similar to the decay time constant of the patch response to a short application of L-cysteate ( $31 \mathrm{msec}$; range, $20-40 \mathrm{msec}$ ) and suggests that the cluster length may determine the decay rate of responses to L-cysteate. In our model, the open state $(O)$ could be construed as an oversimplification of a series of closed and open states that account for the cluster. Since the unbinding rate of L-cysteate is fast, when the channel closes to the $A_{2} R$ state, it will more frequently unbind than reopen or desensitize. This would result in a nearly single exponential decay of a response to a 
short application of L-cysteate that would reflect the cluster length (Gibb and Colquhoun, 1991). In their experiments (Gibb and Colquhoun, 1991), the closures between clusters activated by L-glutamate were not concentration dependent, indicating that L-glutamate usually does not unbind between clusters but rather that the end of a cluster is usually followed by a new cluster. In our model, the unbinding rate of L-glutamate is slower than the reopening rate and the rate into the desensitized state. Thus, once the $A_{2} R$ closed state is reached, the receptor is more likely to reopen, or become desensitized and then reopen. This could account, at least qualitatively, for the long bursts or "superclusters" of openings seen in steady-state recordings (Jahr and Stevens, 1987; Howe et al., 1988, 1991; Gibb and Colquhoun, 1991) and the prolonged decay times of currents evoked by short pulses of L-glutamate. As the kinetics of the bursts of openings in single-channel recordings are the same whether or not they occur in clusters (Howe et al., 1988, 1991; Gibb and Colquhoun, 1991), it is not necessary to postulate the existence of a separate population of kinetically distinct channels to account for either the "superclusters" or the prolonged second component of the L-glutamate current. Although there is no direct evidence for discrete subpopulations, it is possible that distinct channel types occur and could be responsible for the two-component decay of the NMDA EPSC. In other systems, for example, colocalization of two kinetically distinct populations of channels has been proposed to account for the twocomponent decay of nicotinic EPSCs on parasympathetic neurons (Rang, 1981), developing neuromuscular junctions (Sakmann and Brenner, 1978; Fischbach and Schuetze, 1980; Henderson and Brehm, 1989), and GABAergic inhibitory postsynaptic currents (Edwards et al., 1990).

\section{Microscopic affinity constants}

The microscopic affinity $\left(k_{\text {off }} / k_{\text {on }}\right)$ of L-glutamate for the NMDA receptor from our experiments (assuming a $k_{\text {on }}$ of $5 \mu \mathrm{M}^{-1}$; see Clements and Westbrook, 1991) is $0.9 \mu \mathrm{M}$, which is consistent with its affinity measured at equilibrium in binding (Olverman et al., 1988) and physiological studies (Patneau and Mayer, 1990). In order for the model to fit the tail currents evoked by L-cysteate, the unbinding rate had to be increased to about 13 times that of L-glutamate (Table 2). If the binding rates of these two amino acids are the same, the microscopic affinity for L-cysteate would be lower by about 10 -fold than that reported previously (Olverman et al., 1988; Patneau and Mayer, 1990). This discrepancy could be resolved if L-cysteate bound more slowly than L-glutamate. Although there is no direct evidence for differcnces in the binding rates of agonists, competitive NMDA receptor antagonists can have binding rates that vary 26-fold (Benveniste and Mayer, 1991).

\section{Role of different NMDA agonists as transmitters}

Of the agonists tested, we favor L-glutamate as the transmitter at the hippocampal synapse in culture because of the close similarity in its time course with the response of outside-out patches to L-glutamate. The NMDA EPSCs recorded in hippocampal slice also have two-component decays (Hestrin et al., 1990; Randall et al., 1990) with time constants (Keller et al., 1991) similar to those in culture, suggesting that L-glutamate is the transmitter in these pathways. If lower-affinity agonists such as L-aspartate were transmitters, the EPSC would be expected to have a faster decay and a much less pronounced slower phase. Responses to L-homocysteate have a time course only somewhat faster than that of L-glutamate, and on this criterion, L-homocysteate could be considered a transmitter candidate (Do et al., 1986). However, like most NMDA agonists, except L-glutamate, L-homocysteate is a weak non-NMDA ligand (Patneau and Mayer, 1990), and since most synapses studied thus far have a dual-receptor synaptic response (Dale and Roberts, 1985; Wigstrom et al., 1985; Collingridge et al., 1988; Forsythe and Westbrook, 1988), a transmitter role for this compound seems less likely. The present study does not, however, rule out other amino acids as neurotransmitters but suggests that if they were used they would result in EPSCs with faster time courses.

\section{Functional implications of the kinetic properties of NMDA receptors}

In our model of the synaptic NMDA response, the transmitter dissociation rate and the rates in and out of a desensitized state would determine the longevity of the synaptic NMDA response. If receptors at a single release site are saturated, such a model may serve to limit excessive NMDA receptor activation, and perhaps regulate $\mathrm{Ca}^{2+}$ entry through NMDA channels by decreasing their reactivation for some time following stimulation. Conversely, the fact that NMDA receptors are bound for such a long time implies that if release occurs only every few seconds there will always be a proportion of NMDA receptors in the bound state; such activation may be necessary for proper synaptogenesis in development (Cline et al., 1987) and for the longterm maintenance of synaptic efficacy (Bear et al., 1987; Artola et al., 1990).

Some alteration in NMDA channel function clearly occurs soon after pulling a patch that results in an increased rate of desensitization. Whole-cell NMDA receptor desensitization is reduced by high concentrations of glycine (Mayer et al., 1989) and low levels of external $\mathrm{Ca}^{2+}$ (Zorumski et al., 1989; Vyklicky et al., 1990), whereas desensitization of NMDA currents in outside-out patches is reported to be independent of these agents (Sather et al., 1990), suggesting that the act of pulling an outsideout patch alters the properties of NMDA channels. Perhaps a biochemical change such as phosphorylation (see MacDonald et al., 1989), known to affect desensitization in a number of receptor systems (Huganir and Greengard, 1990), underlies this change. Alternatively, some other process may be responsible as suggested for nicotinic ACh channels (Covarrubias and Steinbach, 1990). The similarity in the time courses of the NMDA EPSC and the patch response to L-glutamate suggests that NMDA receptors at synapses may be in the same altered state as those in the patch. At present the data are insufficient to confirm this suggestion, although they raise the possibility of modulation of synaptic NMDA receptors by an alteration in desensitization.

\section{References}

Artola A, Brocher S, Singer W (1990) Different voltage-dependent thresholds for inducing long-term depression and long-term potentiation in slices of rat visual cortex. Nature 347:69-72.

Bear MF, Cooper LN, Ebner FF (1987) A physiological basis for a theory of synapse modification. Science 237:42-48.

Bekkers JM, Stevens CF (1989) NMDA and non-NMDA receptors are co-localized at individual excitatory synapses in cultured rat hippocampus. Nature 341:230-233.

Benveniste M, Mayer ML (1991) Structure-activity analysis of binding kinetics for NMDA receptor competitive antagonists: the influence of conformational restriction. Br J Pharmacol 104:207-221.

Boyd ND (1987) Two distinct kinetic phases of desensitization of acetylcholine receptors of clonal rat PC12 cells. J Physiol (Lond) 389: $45-67$. 
Cha JH, Hollingsworth ZR, Greenamyre JT, Young AB (1989) Contamination of commercially available quisqualic acid by glutamatelike and aspartate-like substances. J Neurosci Methods 27:143-148.

Clements JD, Westbrook GL (1991) Activation kinctics revcal the number of glutamate and glycine binding sites on the $N$-methyl-Daspartate receptor. Neuron 7:605-613.

Cline HT, Debski E, Constantine-Paton M (1987) NMDA receptor antagonists disrupt the retinotectal topographic map. Neuron 1:413426.

Collingridge GL, Lester RAJ (1989) Excitatory amino acid receptors in the vertebrate central nervous system. Pharmacol Rev 40:143-210.

Collingridge GL, Herron CE, Lester RAJ (1988) Synaptic activation of $N$-methyl-D-aspartate receptors in the Schaffer collateral-commissural pathway of the rat hippocampus. J Physiol (Lond) 399:283300.

Colquhoun D, Large WA, Rang HP (1977) An analysis of the action of a false transmitter at the neuromuscular junction. J Physiol (Lond) 266:361-395.

Covarrubias M, Steinbach JH (1990) Excision of membrane patches reduces the mean open time of nicotinic acetylcholine receptors. Pfluegers Arch 416:385-392.

Dale N, Roberts A (1985) Dual-component amino-acid-mediated synaptic potentials: excitatory drive for swimming in Xenopus embryos. J Physiol (Lond) 363:35-59.

Do KQ, Herrling PL, Streit P, Turski WA, Cuenod M (1986) In vitro release and electrophysiological effects in situ of homocysteic acid an endogenous $N$-methyl-(D)-aspartic acid agonist, in the mammalian striatum. J Neurosci 6:2226-2234.

Edwards FA, Konnerth A, Sakmann B (1990) Quantal analysis of inhibitory synaptic transmission in the dentate gyrus of rat hippocampal slices: a patch-clamp study. J Physiol (Lond) 430:213-249.

Fagg GE, Matus A (1984) Selective association of $N$-methyl-D-aspartate and quisqualate types of $\mathrm{L}$-glutamate receptor with brain postsynaptic densities. Proc Natl Acad Sci USA 81:6876-6880.

Feltz A, Trautmann A (1982) Desensitization at the frog neuromuscular junction: a biphasic process. J Physiol (Lond) 322:257-272.

Fischbach GD, Schuetze SM (1980) A post-natal decrease in acetylcholine channel open time at rat end-plates. J Physiol (Lond) 303: 125-137.

Forsythe ID, Westbrook GL (1988) Slow excitatory postsynaptic currents mediated by $N$-methyl-D-aspartate receptors on cultured mouse central neurons. J Physiol (Lond) 396:515-533.

Franke C, Hatt H, Dudel J (1987) Liquid filament switch for ultrafast exchanges of solutions at excised patches of synaptic membranes of crayfish muscle. Neurosci Lett 77:199-204.

Gibb AJ, Colquhoun D (1991) Glutamate activation of a single NMDA receptor-channel produces a cluster of channel openings. Proc R Soc Lond [Biol] 243:39-45.

Grudt TJ, Jahr CE (1990) Quisqualate activates $N$-methyl-D-aspartate receptor channels in hippocampal neurons maintained in culture. Mol Pharmacol 37:477-481.

Hamill OP, Marty A, Neher E, Sakmann B, Sigworth FJ (1981) Improved patch-clamp techniques for high-resolution current recording from cells and cell-free membrane patches. Pfluegers Arch 391:85100.

Henderson LP, Brehm P (1989) The single-channel basis for the slow kinetics of synaptic currents in vertebrate slow muscle fibers. Neuron 2:1399-1405.

Hestrin S, Sah P, Nicoll RA (1990) Mechanisms generating the time course of dual component excitatory synaptic currents recorded in hippocampal slices. Neuron 5:247-253.

Howe JR, Colquhoun D, Cull-Candy SG (1988) On the kinetics of large-conductance glutamate-receptor ion channels in rat cerebellar granule neurons. Proc R Soc Lond [Biol] 233:407-422.

Howe JR, Cull-Candy SG, Colquhoun D (1991) Currents through single glutamate receptor channels in outside-out patches from rat cerebellar granule cells. J Physiol (Lond) 432:143-202.

Huganir RL, Greengard P (1990) Regulation of neurotransmitter receptor desensitization by protein phosphorylation. Neuron 5:555567.
Jahr CE, Stevens CF (1987) Glutamate activates multiple single channel conductances in hippocampal neurons. Nature 325:522-525.

Katz B, Miledi R (1973) The binding of acetylcholine to receptors and its removal from the synaptic cleft. J Physiol (Lond) 231:549-574.

Katz B, Thesleff S (1957) A study of the 'desensitization' produced by acetylcholine at the motor end-plate. J Physiol (Lond) 138:63-80.

Keller BU, Konnerth A, Yaari Y (1991) Patch clamp analysis of excitatory synaptic currents in granule cells of rat hippocampus. J Physiol (Lond) 435:275-293.

Lester RAJ, Quraum ML, Parker JD, Weber E, Jahr CE (1989) Interaction of 6-cyano-7-nitroquinoxaline-2,3-dione with the $N$-methyl-D-aspartate receptor-associated glycine binding site. Mol Pharmacol 35:565-570.

Lester RAJ, Clements JD, Westbrook GL, Jahr CE (1990) Channel kinetics determine the time course of NMDA receptor-mediated synaptic currents. Nature 346:565-567.

MacDonald JF, Mody I, Salter MW (1989) Regulation of $N$-methylD-aspartate receptors revcalcd by intracellular dialysis of murine neurones in culture. J Physiol (Lond) 414:17-34.

Magleby KL, Stevens CF (1972) A quantitative description of endplate currents. J Physiol (Lond) 223:173-197.

Marshall CG, Ogden D, Colquhoun D (1991) Activation of ion channels in the frog endplate by several analogues by acetylcholine. $J$ Physiol (Lond) 433:73-93.

Mayer ML, Westbrook GL (1987) The physiology of excitatory amino acids in the vertebrate central nervous system. Prog Neurobiol 28: 197-276.

Mayer ML, Vyklicky L Jr, Clements J (1989) Regulation of NMDA receptor desensitization in mouse hippocampal neurons by glycine Nature 338:425-427.

Olverman HJ, Jones AW, Mewett KN, Watkins JC (1988) Structure/ activity relations of $N$-mcthyl-D-aspartatc reccptor ligands as studied by their inhibition of $\left[{ }^{3} \mathrm{H}\right] \mathrm{D}-2$-amino-5-phosphonopentanoic acid binding in rat brain membranes. Neuroscience 26:17-31.

Patneau DK, Mayer ML (1990) Structure-activity relationships for amino acid transmitter candidates acting at $N$-methyl-D-aspartate and quisqualate receptors. J Neurosci 10:2385-2399.

Randall AD, Schofield JG, Collingridge GL (1990) Whole-cell patchclamp recordings of an NMDA receptor-mediated synaptic current in rat hippocampal slices. Neurosci Lett 114:191-196.

Rang HP (1981) The characteristics of synaptic currents and responses to acetylcholine of rat submandibular ganglion cells. J Physiol (Lond) 311:23-55.

Sakmann B, Brenner HR (1978) Change in synaptic channel gating during neuromuscular development. Nature 276:401-402.

Sather W, Johnson JW, Henderson G, Ascher P (1990) Glycine-insensitive desensitization of NMDA responses in cultured mouse embryonic neurons. Neuron 4:725-731.

Tang C-M, Dichter M, Morad M (1989) Quisqualate activates a rapidly inactivating high conductance ionic channel in hippocampal neurons. Science 243:1474-1477.

Tang C-M, Dichter M, Morad M (1990) Modulation of the $N$-methylD-aspartate channel by extracellular $\mathrm{H}^{+}$. Proc Natl Acad Sci USA 87: 6445-6449.

Traynelis SF, Cull-Candy SG (1990) Proton inhibition of $N$-methylD-aspartate receptors in cerebellar neurons. Nature 345:347-350.

Trussell LO, Fischbach GD (1989) Glutamate receptor desensitization and its role in synaptic transmission. Neuron 3:209-218.

Vyklicky L Jr, Benveniste M, Mayer ML (1990) Modulation of $N$-methyl-D-aspartic acid receptor desensitization by glycine in mouse cultured hippocampal neurones. J Physiol (Lond) 428:313-331.

Wigstrom H, Gustafsson B, Huang Y-Y (1985) A synaptic potential following single volleys in the hippocampal CAl region possibly involved in the induction of long-lasting potentiation. Acta Physiol Scand 124:475-478.

Zorumski CF, Yang J, Fischbach GD (1989) Calcium-dependent, slow desensitization distinguishes different types of glutamate receptors. Cell Mol Neurobiol 9:95-104. 